\title{
The Function and Meaning of Writing in the Prehistoric Aegean: Some reflections on the social and symbolic significance of writing from a material perspective
}

\author{
Helène Whittaker \\ University of Gothenburg
}

My primary purpose in this chapter is to assess the function and meaning of writing in the prehistoric Aegean by focusing on the material practices of writing. During the Middle and Late Bronze Ages (c.2000-1200 вC) an uncertain number of scripts was in use on Crete. In the pre-Mycenaean period, the two most important are known as Linear A and Minoan or Cretan Hieroglyphic (Figures 1-2; see also Flouda, this volume). Although the two writing systems do not seem to have been used for exactly the same purposes, as they occur on different types of documents, they were both associated with the palatial administration. Linear A is in its earliest form found at the Palace at Phaistos in south-central Crete, while Minoan Hieroglyphic was associated with the palaces at Knossos, Malia, and Petras in the north and northeast (see also Flouda, Finalyson and Tomas, all this volume). Both scripts are syllabic. After the destruction of the first palaces (c.1700 BC), Cretan Hieroglyphic seems to go out of use and is replaced by Linear A for reasons that are still unclear (cf. Finalyson, this volume).

As the two forms of writing can be geographically differentiated in the early palatial period, it is a plausible assumption that they represent different languages, but in view of the fact that neither script has been deciphered this cannot be verified (cf. Olivier 1986: 387; Schoep 1999: 265; 2007; see Younger and Rehak 2008: 176 for the view that there was only one Cretan language). It has, however, been suggested that Linear A and Cretan Hieroglyphic have a common origin in an earlier prepalatial script, known as the 'Archanes script' (Figure 3). This early form of writing takes its name after Archanes in central Crete, where a number of seals inscribed with this script were found in burials (Schoep 1999: 266-267; 2006: 45-46, n. 73). If it is the case that both Linear A and Cretan Hieroglyphic have the same origin, the later development of two different

\section{How to cite this book chapter:}

Whittaker, H. 2013. The Function and Meaning of Writing in the Prehistoric Aegean: Some reflections on the social and symbolic significance of writing from a material perspective. In: Piquette, K. E. and Whitehouse, R. D. (eds.) Writing as Material Practice: Substance, surface and medium. Pp. 105-121. London: Ubiquity Press. DOI: http://dx.doi.org/10.5334/bai.f 


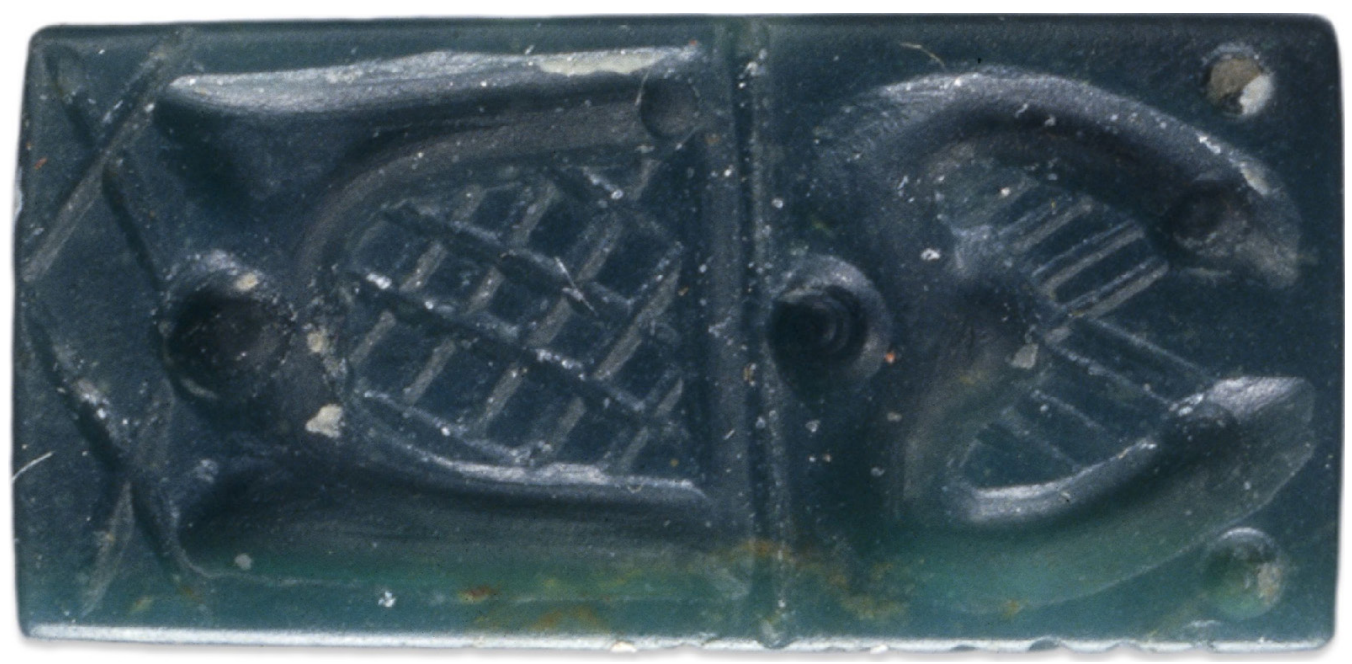

Figure 1: Green jasper seal with signs in the Minoan Hieroglyphic script, side A, from Crete, c.17001550 BC. Length: $1.1 \mathrm{~cm}$; Width: $0.5 \mathrm{~cm}$; Thickness: $0.5 \mathrm{~cm}$. GR 1934.11-20.1 AN34822001. () Trustees of the British Museum.

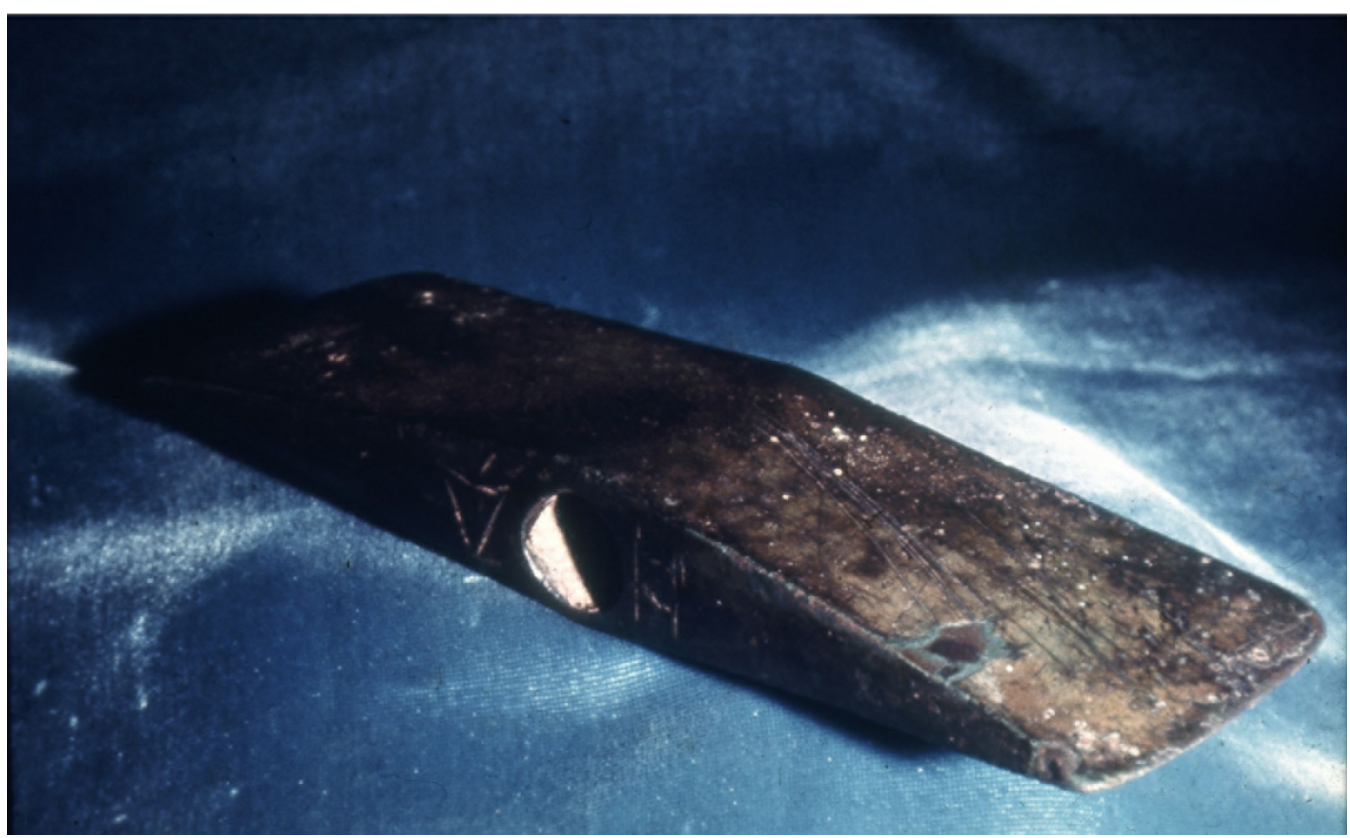

Figure 2: Bronze double axe inscribed with Linear A, said to be from the Lasíthi Plateau, Crete, c.1700-1450 BC. Length: 18.5 cm. GR 1954.10-20.1. ( ) Trustees of the British Museum.

forms of writing associated with the palatial administration in different parts of the island is perhaps to be seen in terms of the deliberate construction of separate regional identities, in which language may or may not have been a factor.

In the Late Bronze Age a new script known as Linear B was invented and became the only script in use on both Crete and the Greek mainland (Figure 4a-b; see Tomas, this volume). Linear B was developed from Linear A in order to write Greek and was closely associated with the Mycenaean 


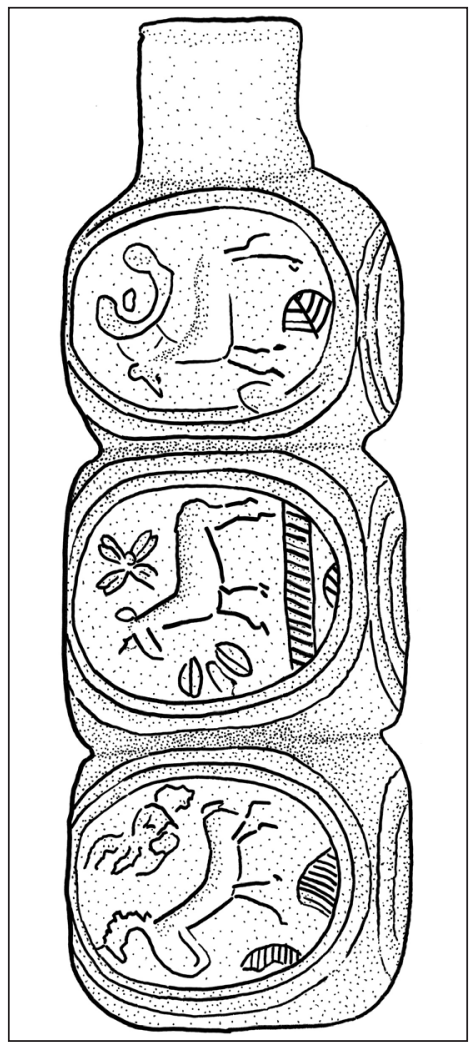

Figure 3: Bone seal with inscribed faces from Archanes c.2000 BC. Length: $4.0 \mathrm{~cm}$. Drawing by Sven von Hofsten (after Sakellarakis and Sapouna-Sakellaraki 1991: fig. 79).

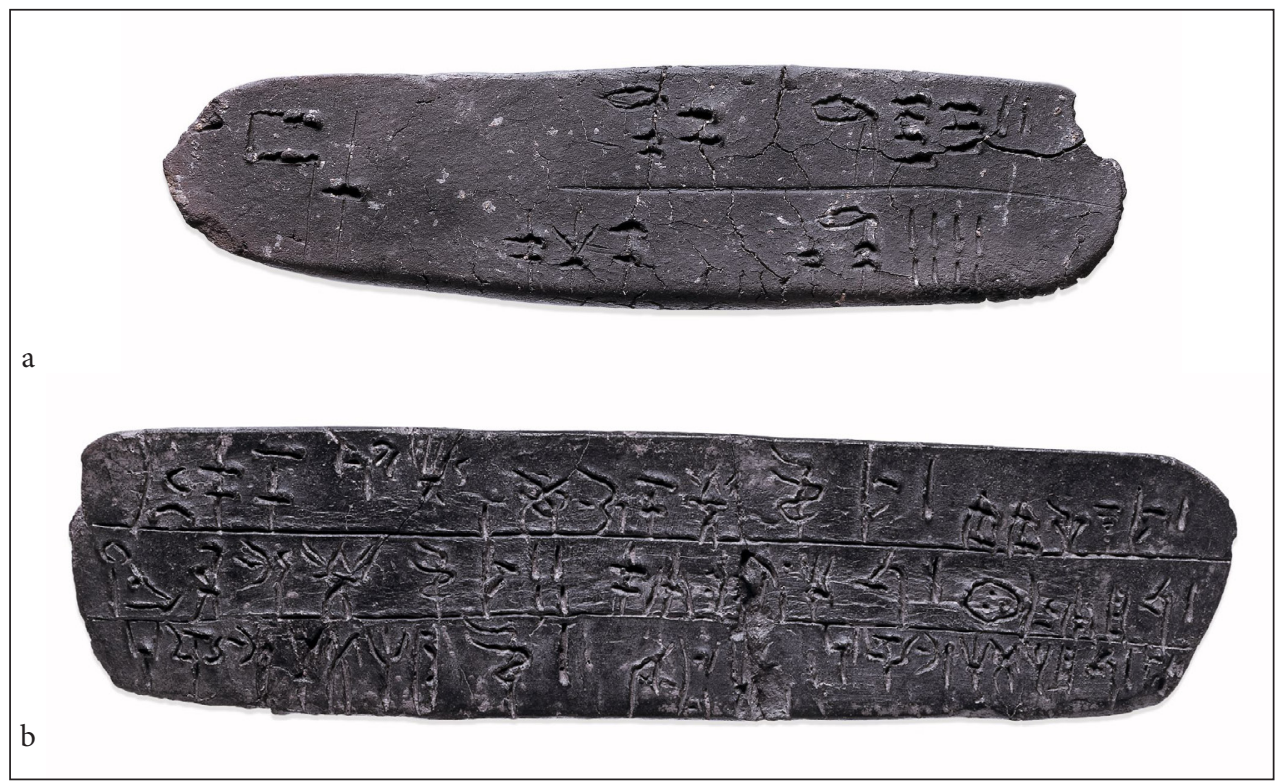

Figure 4: Linear B tablets found at Knossos, 1450-1400 BC. a) GR 1910.4-23.2; b) Length: $16.0 \mathrm{~cm}$; Width: $4.0 \mathrm{~cm}$; Thickness: $2.0 \mathrm{~cm}$. GR 1910.4-23.1. (c) Trustees of the British Museum. 
palace administration. In contrast to Linear A and Cretan Hieroglyphic, Linear B has been deciphered and the documents on which it occurs can be read with a high degree of certainty. Exactly when Linear B was invented is an open question, but it may have been much earlier than the date of the first documents that have been preserved. Whether Linear B was first used on Crete or on the Mainland is also an open question.

A thin clay disc known as the Phaistos Disc represents another possible but controversial example of writing. It was found with a fragment of a Linear A tablet and dates to the Middle Bronze Age. A number of signs, some of them repeated, are arranged in a spiral on both sides of the disc. A few are vaguely comparable to signs of the Cretan hieroglyphic script, but on the whole they bear no conclusive resemblance to either Linear A or Cretan Hieroglyphic. If the signs constitute writing it is in an otherwise unattested form. As a writing support the disc is also unique in its circular shape and in contrast to the clay tablets used in the palatial administrative systems it had been deliberately baked. Strictly speaking, a form of writing that is attested solely on a single artefact should not be really classified as an example of a functional writing system. I have elsewhere suggested that the inscription on the Phaistos Disc could be an example of pseudo-writing (Whittaker 2005; cf. Flouda, this volume).

In the Aegean writing occurs on a number of different types of material supports, made of clay, bone, stone or metal. The use of these varies with time and place. The range of materials used as supports is much more extensive for Crete than for the Greek mainland. Clay tablets represent the largest group of preserved texts. Their use was associated with the palatial administration on both Crete and the mainland and spans the Middle and Late Bronze Ages. Their first occurrence is associated with the establishment of the Minoan palace system c.2000 вс. The latest tablets date to the destruction of the Mycenaean palaces $c .1200$ BC. Clay was a material that was readily available, as good sources are found on both Crete and the Greek mainland. Clay tablets are objects that have been fashioned solely for the purpose of being written on, and their shape and size would have been determined by the specifics of this use, by the system of storage, or by the needs of the scribes. They were used for all three of the major scripts, and the shape of the tablet correlates with the type of writing found on them. Cretan Hieroglyphic is generally found on two-sided or four-sided bars, while Linear A and Linear B are found on page-shaped tablets; the ones used for Linear A are generally smaller than the ones used for Linear B. Linear B is also found on tablets which are much wider than they are long (often called leaf-shaped or palm leaf-shaped). The tablets sometimes have writing on more than one side; the four-sided bars are generally inscribed on all sides. All types of tablets were made in the same way. After being fashioned from the wet clay, they were air-dried until they had hardened to the consistency of leather and were ready to be written on. Some kind of stylus with a sharp point was used for writing. It has been claimed that the function of several thin rods made of bone and in one case of bronze found at Tiryns was for writing Linear B (Cultraro 2006: 24). Otherwise, styli have not been recognised in the archaeological record, which may be an indication that they were commonly made of wood and thus less likely to survive. This is perhaps indicated by the fact that some inscriptions include the impressions of a stylus that had been roughly made and in some cases had a split end (Hallager 1996: 29). Chadwick (1976: 18) suggests that a thorn fastened to some kind of holder could have been used for the very fine writing found on some tablets.

When a scribe had finished recording information on a tablet it was left to dry completely before being placed in a basket or a wooden container and archived. It was possible to reuse a tablet which had already been inscribed and dried by moistening it so that the surface could be flattened and whatever had been written on it erased. When it had dried sufficiently, the tablet could then be re-inscribed. Many Linear A tablets are in fact palimpsests, indicating that the palace bureaucracies had some kind of recycling scheme in place (Schoep 2002: 79). The use of clay tablets can be seen as providing material weight and durability to the information recorded on them. It is, however, possible that for certain types of texts in the palace bureaucracies, clay may have been 
chosen as a support because its material properties afforded impermanency as much as permanency (see also Piquette, this volume). In light of evidence for re-use, the information recorded on clay tablets, in all or most cases, may have been of an ephemeral nature. Nevertheless, since all Aegean tablets were unbaked, their survival as archaeological artefacts was dependent on them being exposed to fire in some other way. The majority that have been preserved as legible documents have been found in the destruction layers of the palaces, which they do not in most cases antedate by long periods of time.

Other types of clay objects that may carry script are the so-called roundels, various types of sealings, and ceramic vessels used for storage or transport. Roundels are thick clay disks with seal impressions, which have usually been inscribed with signs in Linear A on one or both faces (see also Finalyson, this volume). Their function is uncertain, but almost all have been found in archival contexts; one suggestion is that they were receipts given in return for the delivery of goods from the palaces (Hallager 1996: 116-120). Their use is restricted to the period of the new palaces on Crete $(c .1700-c .1450 \mathrm{BC})$. All three scripts can occur on sealings. However, while a stylus was always used to write Linear A and B on all types of clay documents, Cretan Hieroglyphic could also be written with seals, which were pressed into the clay in order to produce a meaningful text. Like the tablets, roundels and sealings have only been preserved if they have been accidently burnt. All three scripts can also be found either inscribed or painted on different types of ceramic vases. Texts in Linear B were normally painted on the pots before they were fired. Inscriptions on pots were meaningful in the sense that they were intended to provide information about place or time of fabrication, ownership or function. Potsherds, often referred to with the Greek word ostraka, were commonly used for informal writing in the historical Greek period (Thomas 1992: 57, 83 compares them to our scrap paper). This does not seem to have been the case in the Bronze Age. As far as I know, the only example from the prehistoric Aegean is an ostrakon from Akrotiri on Thera in the Cyclades, which has some kind of calculation in Linear A scratched on it (Michailidou 1992-1993).

\section{Stone}

On Crete writing is found on stone artefacts of various types. The Archanes script is found on three seals made of steatite (Godart 1999; Olivier and Godart 1996: \#201, \#203, \#251; Schoep 2006: 45). This is a stone that is widely used on Crete as it is fairly soft and therefore easy to work. Two other seals with the Archanes script are made of marble and agate; as these stones are harder to work they may be later in date (Olivier and Godart 1996: \#205, \#292). Soft stones such as steatite or serpentine were used to make the earliest seals with inscriptions in Cretan Hieroglyphic. When the introduction of the horizontal bow-lathe in the $17^{\text {th }}$ century $\mathrm{BC}$ made it possible to inscribe harder stones, red carnelian or green jasper also occur (Rehak and Younger 2001: 403). Serpentine and steatite were locally available on Crete, and there are a few sources of marble (Warren 1969: 134-135, 138-141). Green jasper (also known as antico verde) was imported from the Greek mainland, while agate and carnelian may have come from Egypt. Most of the seals inscribed with Cretan Hieroglyphic have three or four faces, of which one or two carry writing. Seals were used to impress clay and the fact that the earliest writing on Crete is found on seals implies the use of clay sealings and possibly other types of documents made from clay from the time that writing was invented on Crete.

Inscriptions in Linear A are found on a number of stone vessels that have been classified as libation or offering tables (Schoep 1994; Warren 1969: 62-68; Figure 5). These offering tables belong to a fairly well-defined type; they are usually square in shape and have a round bowl in the centre. They are made of serpentine, steatite or limestone. The inscription is sometimes on the wide flat rim surrounding the bowl, but in some cases it is found on the sides of the table. A sharp, 


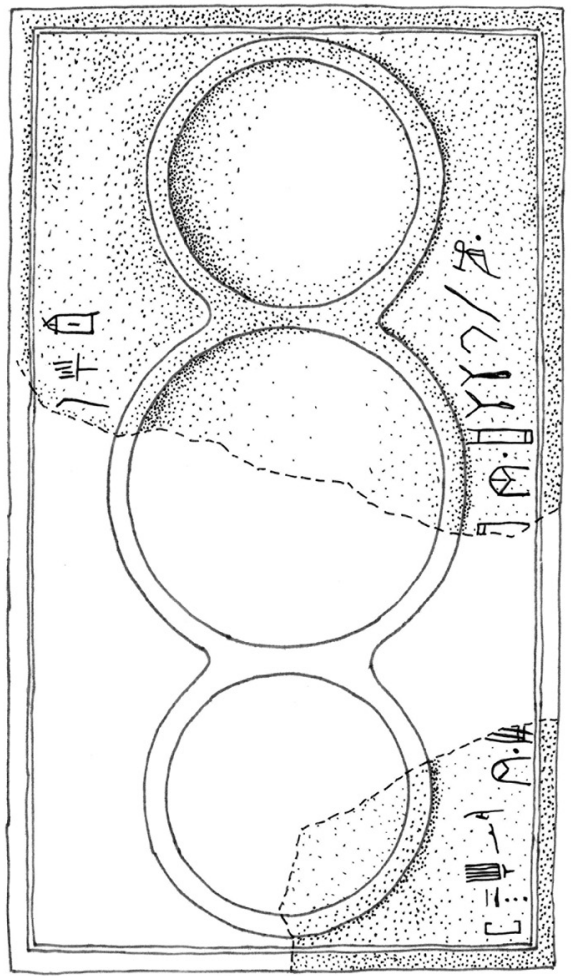

Figure 5: Steatite offering table with Linear A from the Psychro Cave c.1600 BC. Length: $c .20 \mathrm{~cm}$. Drawing by Sven von Hofsten (after Bendall 2013: fig. 256-257).

pointed implement was used to scratch the inscriptions onto the surface of the stone. The stone vases with inscriptions in Linear A date to the period of the new palaces. They have most often been found in cultic contexts, but some examples have been found in domestic contexts (Schoep 1994: 11). This practice of inscribing stone contrasts in material, purpose and context with the use of (recycled) clay in the administrative system of the palaces, surfaces fashioned expressly to carry writing.

On the Greek mainland writing is found on stone only very rarely. A fragment of schist with two Linear A signs was found at Ayios Stephanos in Lakonia (Janko 1982). It probably dates to the early Mycenaean period. The nature of the object is obscure, but it may be a weight. Two Linear A inscriptions on grave markers dating to the beginning of the Late Bronze Age have been illustrated by Evangelia Protonotariou-Deilaki (1990: fig. 28). One comes from Argos, the other from Grave Circle A at Mycenae.

Although perhaps not 'writing' strictly speaking, mention can also be made of the so-called mason's marks which first appear at the beginning of the Middle Minoan period. These are signs that have been inscribed on stone building blocks, which would have been mostly, but not always, invisible after the building had been completed. Mason's marks include the depiction of stars, double axes, branches and tridents, and they can be compared to signs in the Archanes Script, Cretan Hieroglyphic and Linear A. They have also in a few isolated cases been found on the Greek mainland. At Peristeria in Messenia two mason's marks of Minoan type, a double axe and a branch, had been cut into the facade of Tholos 1, a monumental burial structure, while three, one trident and two branches, have been identified on stone blocks at Mycenae; a double axe occurs on a building block on a wall below the palace at Pylos (Hood 1984: 36; 1987). 


\section{Metal}

Writing is also found on metal artefacts. Linear A inscriptions have been found on at least six double axes made of bronze from various parts of Crete (Fri 2007: 68-71). The inscriptions had been made on finished axes. They are all functional axes and several of them show clear evidence of use. A bronze cauldron from Grave IV of Grave Circle A at Mycenae, which has what seems to be a single Linear A sign inscribed near the handle, represents, with the schist fragment and the grave markers mentioned above, one of the very few examples of Cretan writing found on the Greek mainland (Karo 1930-1933: no. 576; Palaima 2003a). Linear A inscriptions occur on three miniature replicas of double axes made of gold, which have been found at Archalochori in central Crete (Marinatos 1935). A large double axe made of bronze was also found in this deposit. It carries an incised inscription, arranged in three vertical columns, in the middle on one of its faces. The signs on the Archalochori Axe are idiosyncratic, and like the Phaistos Disc this may be an example of pseudo-writing (Whittaker 2005). A gold ring and four pins made of gold or silver also have texts in Linear A (Alexiou and Brice 1972; 1976; CMS II.3:38; Godart and Olivier 1982: KNZf13, KR(?) Zf1, PLZf1, KNZf31; Olivier et al. 1981; Platon and Pini 1984: 38). Crete is poor in metals and the copper and tin needed for bronze, as well as gold and silver, must have been imported. Gold and silver, and perhaps also bronze, represent rare and valuable materials (Watrous 2001: 165; Rehak and Younger 2001: 415). However, the range of metal objects on which writing is found on Crete suggests that writing may have been in more common use on materials which do not survive well than the actual archaeological evidence would indicate.

\section{Bone}

The evidence for the use of bone as a support for writing is limited to a few seals. With one exception the seals found at Archanes are made of bone (Olivier and Godart 1996: \#202, \#252, \#315; Sakellarakis and Sapouna-Sakellaraki 1997: 326-330). The six seals with script from Archanes were found in Burial Building 3, Burial Building 6, and Burial Building 7, which date to the Middle Minoan IA period (c.2000-1900 вC). The largest has the form of three superimposed cubes, giving 14 sealing surfaces, of which two bore writing (Figure 3).

\section{Other Materials}

All preserved examples of Aegean writing are on clay tablets or other administrative documents that have been recovered from destruction layers of buildings destroyed by fire, or on small-scale objects made of durable materials whose survival was dependent on archaeological chance. It is clear that various kinds of perishable materials, such as leather, wood or papyrus, could have been, and almost certainly were, used to write on. The nature of the scripts themselves provides one indication that this was the case. The signs of Linear A and B are quite complex and consist of curved as well as straight lines. They are therefore more suited to writing or painting with ink on papyrus or pottery than to being inscribed in semi-dried clay (Chadwick 1976: 27; Palaima $2003 b$ : 171). This suggests that some form of 'paper' support was used from an early period. It is possible that the development of Linear A from the Archanes script, which, as far as we know, could only be written by pressing seals into clay, should be seen in relation to the availability of imported papyrus or the acquisition of a technology for turning animal skins into a suitable writing surface. Since contacts between Crete and Egypt go back to the Early Bronze Age, it is not unlikely that papyrus was imported and used as a writing material also on Crete. A type of sealing known as the single-hole hanging nodule consists of a triangular lump of clay which had been 


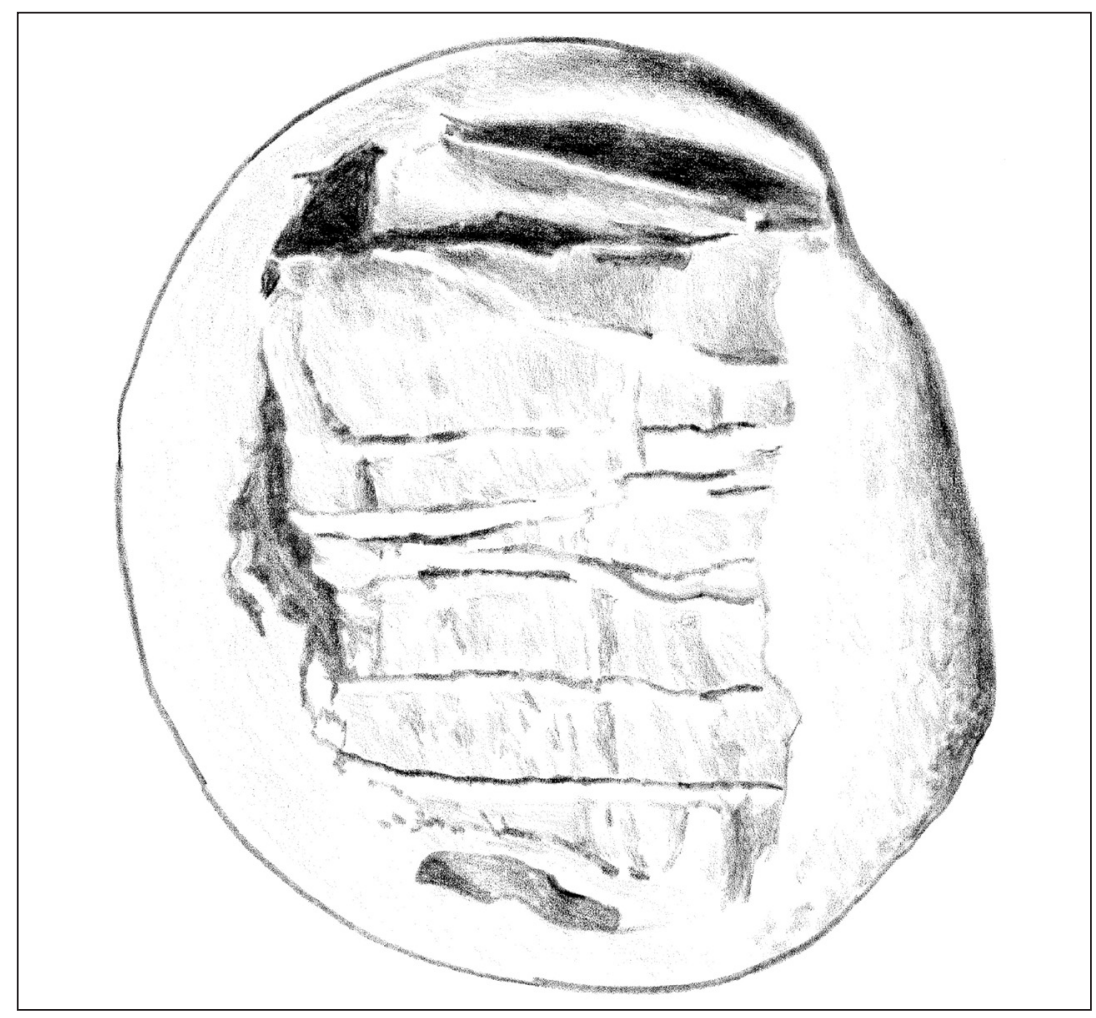

Figure 6: Flat-based nodule. Diameter: $2.1 \times 2.75 \mathrm{~cm}$. Drawing by Sven von Hofsten (after Hallager 1996: fig. 55).

formed around a knot at one end of a string. Hallager has argued that nodules of this type were attached to the string used to fasten papyrus documents (Hallager 1996: 198-199). However, the only things that are known for certain about the function of the single-hole hanging nodules is that they were attached to string and that they must have been used for some specific purpose in the Minoan palatial administration. The majority of them were inscribed in Linear A, usually only with a single sign, which may have indicated the category to which whatever they were attached to belonged.

A type of sealing known as flat-based nodules has more certainly been regarded as evidence for lost types of texts. These are lumps of clay with one or more seal impressions; in some examples impressions on the base of the nodules show that they had been attached to pieces of very thin leather which had been tightly folded and tied with thin string (Figure 6). This has led to the suggestion that leather or even parchment was in common use for writing (Hallager 1996: 135-158; Weingarten 1983: 38-42; see also Chadwick 1976: 27-28; Krzyszkowska 2005: 156; Schoep 2006: 56, n. 2; Shelmerdine 2008: 12; Younger and Rehak 2008: 175). It is in fact hard to imagine what other than written documents the folded and sealed pieces of leather could have been.

Like papyrus, leather and parchment, wood has few chances of survival in the Greek soil. Evidence from later periods of Greek antiquity and from contemporary Egypt and the Near East shows that wood could be used quite extensively for different type of supports for writing. Wooden boards covered with stucco and textile, which could be written on in ink, were used in Egypt from the Old Kingdom onwards (Cribiore 1996: 65). For all we know, similar wooden boards could have been in common use on Crete. Numerous inscriptions on stone survive from Greece in the historical period, testifying to the use of writing in official contexts and public display. However, 
textual evidence indicates that large whitened wooden boards were also used for public notices in Athens (Thomas 1992: 83). None of these survives, but as pointed out by Rosalind Thomas, wooden boards rather than stone might in fact have been the main medium for official inscriptions. There is no reason why wooden boards could not have been used in the Bronze Age as well for a similar purpose. The possibility that monumental public inscriptions existed in the Bronze Age Aegean cannot be completely ruled out, despite the total absence of evidence. It can, however, be considered certain that stone was not used, as in that case one would have expected some fragments at least, if not entire texts, to have survived.

\section{Writing-boards}

Chance survivals can on rare occasions provide a glimpse of lost types of text-objects. Fragments of a wooden writing-board were found in a $14^{\text {th }}$-century BC shipwreck off the south coast of Turkey near Ulu Burun (Bass et al. 1989: 10-11; Payton 1991). It is of a type which, as is now clear, was in use from the Bronze Age to the Medieval period (see Brown 1994 on Medieval writingboards). The Ulu Burun writing-board consists of two rectangular pieces of wood, the insides of which, apart from a border along the edges, had been hollowed out to allow them to be filled with wax. The two boards were joined by ivory hinges on one of the long sides and when closed could be fastened with string or leather thongs. Although the wax has not been preserved, it was probably coloured as seems to have been the case generally with ancient and medieval writing-boards (cf. Brown 1994: 7; Clanchy 1979: 91; Lalou 1992: 234; Small 1997: 146). Adding colour to the wax would have had a decorative function, but it would also have made the inscribed characters easier to read. Black was the most common colour, but red, yellow or green could also occur. An $8^{\text {th }}$-century BC wooden writing-board from Nimrud in Mesopotamia was found with some of its wax preserved. Analysis showed that it consisted of $25 \%$ orpiment, which would have given it a brilliant yellow colour (Mallowan 1954: 98-99). Orpiment, which was in common use as a pigment in Antiquity, was in fact found in an amphora on the Ulu Burun wreck (Bass 1986: 278-279; Bass et al. 1989: 10-11). The remains of two other wooden writing-boards from the Ulu Burun wreck have also been identified (Shear 1998: 187). Since the contents of the ship included goods and artefacts from different parts of the eastern Mediterranean, it is impossible to determine their provenance; they could be Syrian, Egyptian, Cypriote or Mycenaean (cf. Symington 1991: 112). There is ample textual evidence for the perhaps widespread use of wooden writing-boards in the Near East from the time of Ur III (Symington 1991: 111; MacGinnis 2002). As stressed by Nicholas Postgate, Wang Tao and Toby Wilkinson, the Ulu Burun writing-boards should be regarded as representatives of what may have been a large and important class of Bronze Age objects (Postgate et al. 1995: 478; cf. MacGinnis 2002: 227).

Information on the specific uses of Near Eastern writing-boards relies on evidence from texts which sometimes mention the type of document on which specific information was recorded. The fact that no evidence of this type exists for the Aegean cannot be taken to preclude the idea that wooden writing-boards might have been used in similar ways. If wooden writing-boards were used in the Aegean in the Bronze Age, it is possible that they were used for different types of texts than those found on clay tablets. Since wooden writing-boards are lighter and stronger and therefore less cumbersome than clay tablets, it is possible to imagine that they were used for transporting information from one place to another. A wooden writing-board can be worn about the person (hanging from the belt vel sim.), and would therefore be suitable for quickly noting down information in passing, which could then later be transferred to a clay tablet or a papyrus document (cf. Brown 1994: 9; Clanchy 1979: 91-92 for this use of wooden writing-boards in the Medieval period). The wax surface used to write on could be easily wiped clean and reused. Wooden writing-boards may also have been used for writing of a more permanent character. In 
the Near East they were in some periods extensively used along with clay tablets for accounts and inventories of a permanent nature (MacGinnis 2002; Symington 1991: 118-123).

Hinges from wooden writing-boards made of ivory or bronze (or fragments thereof) should be fairly easy to recognise in the archaeological record, but no certain examples from Minoan Crete or the Greek mainland have been published. Ione Mylonas Shear has suggested that seven bronze hinges with traces of burnt wood found with Linear B tablets at Knossos and twelve bronze hinges found with Linear A tablets in the Archive Room of the palace of Zakro might represent the remains of wooden writing-boards (Shear 1998; cf. Perna 2007). Seven bronze hinges were found along with clay tablets and sealings in the Archive Complex of the Palace at Pylos (Palaima 2003b: 181; Shear 1998). One of the hinges from Pylos preserved traces of carbonised wood. In both cases, the hinges have been identified as the remains of wooden boxes, used for storing clay tablets (Platon 1971: 151). However, as argued by Shear, it would seem more likely that they represent the remains of writing-boards as their size corresponds to that of the ivory hinges from the Ulu Burun writing-board. Hinges of the type used on the writing-board from the Ulu Burun wreck could have been made from wood just as well as from ivory. The hinging system on the Ulu Burun writing-board is quite elaborate, as well as being made of a prestigious material. It would therefore seem reasonable to assume that wooden writing-boards may have more commonly been hinged or tied together with string or leather cords. Massimo Perna's objection that the fact that large numbers of bronze, bone or ivory hinges have not been found in archival contexts (or elsewhere) could be an indication that wooden writing-boards were not in common use in the Aegean area may therefore not be valid (Perna 2007: 226). Clay sealings may document the use of wooden writing-boards on Crete. In this regard, particular mention can be made of the balls of clay with seal impressions called two-hole hanging nodules which were used to fasten the two ends of a string together. They are believed to have been used to seal and / or label moveable commodities, although exactly what is uncertain (Hallager 1996: 36-37, 159-199; Krzyszkowska 2005: 21). Clay lumps called crescents with inscriptions in Cretan Hieroglyphic were also formed around string and are assumed to have sealed containers of some kind such as bags or boxes (Schoep 2004: 287). Alternatively, it would seem possible to suggest that the function of these types of sealings was to seal the string which tied the two parts of a wooden writing-board together. It may be relevant in this connection that the two-hole hanging nodules have been found with other archival documents. Some of the clay crescents are inscribed with signs that can be identified with logograms signifying wine, grain and olives (Schoep 2004: 287). If they were used to seal wooden writingboards, it would seem to imply that these were used for archival purposes.

\section{Social and Symbolic Implications}

Because clay tablets found in archival contexts constitute by far the largest group of artefacts carrying script, most interest in Aegean Bronze Age writing has concentrated on its use as a bureaucratic tool. The invention of writing on Crete towards the end of the $2^{\text {nd }}$ millennium $\mathrm{BC}$ has been regarded as a result of or even necessitated by the transition from small-scale to the more complex palatial societies. The fact that writing first occurs on seals rather than on other types of objects can be seen as first and foremost a consequence of developments in the administrative system but it can be proposed that the use and display of writing was also intertwined with social and symbolic meanings. In the rest of the chapter I shall try to evaluate the non-utilitarian functions of writing in the Bronze Age Aegean.

As stated above, the earliest form of writing is the Archanes script which is found on seals made of bone or stone. The invention of the Archanes script predates the establishment of the palaces and centralised administration. Only about 10 signs in all are represented in the Archanes 
script, and it might therefore be questioned whether it can reasonably be regarded as writing in a strict sense of the word. It could be argued that the signs represent rather some form of complex iconography and had a more decorative function (cf. Krzyszkowska 2005: 70-71; Shear 1998). However, in addition to the fact that several of the signs occur more than once, similarity with signs in Linear A would seem to indicate that they represent the sounds of words and that the inscriptions record meaningful text (cf. Schoep 2006: n. 74). Most seals with the Archanes script were found at Archanes in central Crete, but some have been found elsewhere and it is possible that the earliest form of Aegean writing may have been more widespread than is indicated by the available evidence.

That seals were used sphragistically for administrative purposes in Prepalatial Crete seems certain. Even though clay sealings which can be dated to this period are not many, the fact that they do exist can be regarded as incontrovertible evidence that seals were actually used to seal something and were not or not exclusively used for personal adornment or as amulets (Krzyszkowska 2005: 77-78; Pini 1990: 34-37; Schoep 1999). There is therefore no reason to doubt that the seals with early writing were also used for sealing purposes. The fact that Minoan writing first occurs on seals can plausibly be seen as an extension or elaboration of the administrative system that was already in existence. There is a continuity of use into the Palatial period in that seals inscribed with Cretan Hieroglyphic occur after the Archanes script has been superseded.

In addition to their administrative use, it is likely that seals functioned as badges of authority and were important status symbols from the Prepalatial period onwards. In the Palatial period this is most clearly indicated by the use of colourful, valuable and imported materials. The fact that seals are often perforated probably indicates that they were intended to be worn visibly as ornaments. In the Prepalatial period, when bone and mostly soft and locally available stone types were used, an association with the expression of individual prestige is, as proposed by Alexios Karytinos, perhaps indicated by the many different and in some cases elaborate shapes of the seals (Karytinos 1998: 79; cf. Krzyszkowska 2005: 21; Schoep 2006: 50). In the Prepalatial period Archanes seems to have been an important and wealthy centre (Sakellarakis and Sapouna-Sakellaraki 1991). The evidence comes primarily from the cemetery at Phourni, where several monumental burial structures were uncovered. The earliest dates to the middle of the $3^{\text {rd }}$ millennium $\mathrm{BC}$. These burials undoubtedly represent the emergence of an increasingly hierarchical society, and the grave goods attest to the wealth, far-flung connections, and prestige of those buried there. It would seem not implausible that writing was first invented at Archanes. The finds in Burial Building 6, where four of the seals with writing were found, were particularly rich and included jewellery, amulets made of bone, ivory, and gold, seals made of ivory and steatite in a variety of shapes and with different types of scenes, both figural and geometric, an Egyptian faience scarab, clay figurines, bronze tools, stone vases and many clay vessels (Sakellarakis and Sapouna-Sakellaraki 1991: 98-104; 1997: 202-205). It is certainly significant that in its earliest occurrence Aegean Bronze Age writing is found associated with prestige items in rich burials which attest to the wealth and social standing of their owners (cf. Karytinos 1998; Schoep 2006: 46-47). This can furthermore be seen in the context of the social importance of funerary ritual to the display of power and status in this period (Branigan 1970: 130-138; Murphy 1998: 36-39).

Also noteworthy is an apparent link between the earliest writing on Crete and religious expression. The signs in the Archanes script include representations of a double axe, a jug, a bucranium, a branch, a sistrum, objects that almost certainly had religious connotations (Nikolaidou 1999; Sakellarakis and Sapouna-Sakellaraki 1997: 351-356). It would seem significant that the earliest form of Aegean writing was based on signs which were imbued with religious meaning. Some of these signs also continue into the later Cretan writing systems. The signs found on some of the seals have been compared to the inscriptions in Linear A on stone vessels from cultic contexts. This could indicate that the inscriptions in Archanes script record religious texts (Sakellarakis and 
Sapouna-Sakellaraki 1997: 329; Schoep 1999: 266, 273, n. 4). If that is the case, it is possible that the text was intended to enhance the function of the seal by providing additional religious protection when it was used to seal something. It is also possible that the seals with inscriptions were used mainly or exclusively for religious purposes. The seals themselves may furthermore have functioned as a sign of religious status or authority of some kind, and may have served to identify the owners as high-standing religious functionaries.

There has been some debate concerning the reasons for the invention or initial use of writing, whether a utilitarian or a symbolic function should be seen as primary (see e.g. Cornell 1991; Postgate et al. 1995; Stoddart and Whitely 1988; Thomas 1992). When it comes to Crete in the Bronze Age, it can be suggested that the distinction between a utilitarian function, on the one hand, and a ritual or ceremonial function, on the other, represents a false dichotomy. Religious ideology was most likely an integral part of the economy and the administrative system in the Prepalatial as well as in the Palatial periods, and there may not have existed any meaningful distinction between religious significance and administrative sphragistic use. It is arguable that the ideological and religious meanings associated with early Minoan script as seen at Archanes were part of the background against which the development of Cretan Hieroglyphic and Linear A and the uses of writing in the palatial administration should be seen.

The clay tablets with Linear A and Cretan Hieroglyphic represent an administrative development that can be associated with the establishment of palatial rule on Crete. The largest number of tablets has been found in palatial archives. However, a number of tablets with Linear A come from other contexts on Crete and in a few cases also from outside the island, testifying to the relatively widespread currency of this script. How, when, and if the information recorded on the clay tablets, which were kept in the palace archives, was later consulted is difficult to reconstruct. Despite the fact that clay tablets were clearly meant to be preserved for some length of time, it is often assumed that they represent temporary records, and that the information on them was later transferred to more permanent archival documents, for which papyrus or some other material which has not been preserved would have been used (Hallager 1996: 32; Olivier 1986: 386-387; Schoep 2006: 55). The fact that many of the Linear A tablets have been recycled is seen as evidence for the view that the clay tablets were temporary records (Schoep 2002: 79). Although clay as a material was readily available, the production of tablets of a standard type can be considered a fairly elaborate process that must have involved a number of people in the palace administration, including scribes who had specialist skills and may have worked full-time. From that perspective it is hard to understand why clay tablets would have been chosen as a medium for temporary documents.

It can, however, be suggested that whatever their function in the administrative processing of information the clay documents were also symbolic objects which played a role in expressing the power of the ruling elite. The possession of information is an effective instrument of political power, and this would have been clearly expressed through the bulky materiality of the clay tablets, regardless of whether they were ever consulted at a later date. It is also possible that the act of recording the goods that came into the palaces on clay tablets may in itself have been intended most of all to impress visitors with the control of the palatial elites over resources, labour and people. The ability to use a common material such as clay to transform speech into material form may also have been seen as a reflection of divine power. The fact that in many instances the information which is written down is minimal could suggest that the contents of the text were in some sense of secondary importance. The palace archives may not then have been intended as repositories of information that could be consulted by officials when necessary, but more as a display of the capability of the palace administration to collect and store information. If that was the case, it would not have been necessary to preserve the information on the tablets for long periods and they could be reused as needed. 
The inscribed stone offering tables which have been found in cultic contexts constitute clear evidence for an association between writing and ritual (see also Flouda, this volume). Several of the inscriptions consist of the same recurring sign groups, usually transcribed as A-SA-SA-RA. It would seem likely that this represents a dedicatory formula. The purpose of the inscription, which is found only on very few of the stone vessels found in sanctuaries, may have been to increase the value of the object and to provide a permanent record of the wealth and piety of the dedicator (Schoep 1994: 20; 2006: 57; Whittaker 2005: 30). The display of writing could in that case be said to have functioned as a means of commemoration and authentication. The fact that these inscriptions occur on objects that are made of a durable material further suggests that the permanence given to the act of dedication by being recorded in writing and the indestructible nature of the material of which the objects are made were believed to reinforce each other.

It can be argued that the fact that writing occurs on double axes made of metal reflect the same idea. A few double axes made of bronze have been incised with one or two signs in Linear A (Figure 2). Although it is clear in some cases that they had been used as tools, it is possible that the inscription marks them as votive offerings that had been deposited in a sanctuary. Unfortunately, their find contexts are generally uninformative and several have no known provenance. The double axes made of gold that were found at Archalochori, on the other hand, were miniatures made of thin foil and could not have had any practical function. They can be classified as votive replicas. It may be relevant in this connection that in addition to durability and immutability, gold as a material is characterised by its bright and glowing colour. Evidence from different cultural contexts show that the quality of luminosity is universally or near-universally perceived to be associated with the materialisation of the supernatural (Keates 2002; Parisinou 2005). It is arguable that the use of gold for votive objects was intended to express an association with divinity, which was reinforced by the inscriptions. Along these lines, it could be proposed that examples of writing on gold and silver jewellery, which were presumably worn by members of the elite, were intended to demonstrate not only social status but also religious authority.

As discussed above, the question of whether wood was used as a support for writing in the Aegean Bronze Age continues to remain open, as there is no decisive archaeological or textual evidence from the Bronze Age Aegean itself. It is therefore not easy to speculate about possible social or symbolic meanings. In the Iliad there is, however, a single mention of a writing tablet, which may be of relevance in this connection. In the passage in question, king Proitos of Argos is described as sending the prince Bellerophon, whom he wishes to get rid of, to his kinsman in Lydia with a letter asking that the bearer be killed (Iliad VI.168-169). The letter is described as being written on a double tablet which could be folded together. It is not stated explicitly that it was made of wood, but had it been thought of as made of some other material this would no doubt have been included in the description. Accordingly, it can be assumed that the poem's audience was meant to imagine a wooden writing-board. While the Iliad was not composed and written down before the $8^{\text {th }}$ century, Greek epic poetry has its roots in the Bronze Age. It is therefore possible that the occurrence of a writing-board as a crucial element of this story reflects the material culture of the Bronze Age. The recovery of several writing-boards from the Ulu Burun wreck raises considerably the odds in favour of the possibility that the story of Bellerophon reflects the use of wooden writing-boards in the Mycenaean period for communication over geographical distance (cf. Shear 1998: 189).

The more or less complete wooden writing-board from the Ulu Burun wreck was found in a pithos, which also contained the substantial remains of pomegranates, probably indicating that the jar had been filled with the fruit, several ballast stones, a bronze chisel and a bronze razor (Bass et al. 1989: 10-11). This has been taken to indicate that it contained information concerned the ship's cargo (Perna 2007: 226). However, the Ulu Burun writing-board was clearly an object of some value and on that account it seems unlikely that it and the two other writing-boards of 
which fragments were found in the wreck had been used for keeping track of the merchandise (Payton 1991: 106). It could be speculated that they rather represent diplomatic correspondence (cf. MacGinnis 2002: 221; Symington 1991: 119-120 on the use of writing-boards for letters in the Near East in the Bronze Age). If that was the case, the boards themselves may have played a role in elite gift exchange. Although perhaps not outstandingly valuable objects, the wooden writing-boards from the Ulu Burun wreck would have been striking artefacts with their ivory hinges and brightly coloured writing surfaces. As modern top level gift exchange demonstrates, the gifts themselves need not always be characterised by expense or exclusivity (e.g. President Obama's gift of an iPod to Queen Elizabeth II, see also Sparks' discussion of gift exchange, this volume). In the Iliad, the fact that King Proitos writes his message on a writing-board rather than on a rolled or folded and sealed piece of papyrus is possibly a reflection of the use of writing-boards as gifts between rulers in the Mycenaean period (cf. Shear 1998; see also Crielaard 1995: 213-124).

\section{Concluding Remarks}

In the Aegean writing is found on a fairly wide range of materials and in this chapter I have attempted to provide a concise overview of the various forms of writing and materials, as well as of other types of supports that have not been preserved, but may have existed. It is evident that beyond its primary function as a medium for storing and conveying information in a stable form, writing was in many contexts associated with various social and symbolic meanings, relating to power, status and religious expression. These meanings were associated with the nature of the writing itself and the materials used as supports, and with the contexts in which writing occurred. There was thus an interdependence between text types and the materials that the artefacts on which they are found are made of. This is well illustrated by the occurrence of writing on objects made of materials, such as stone or gold, which have been found in ritual contexts. The fact that the durability of these materials was reinforced by an inscription which gave permanence to the act of dedication enhanced the meaning of the artefacts as votive offerings. Conversely, the use of clay tablets, which were cumbersome, but which could also be easily erased and reused, in the palatial administrative systems suggests that permanence of information was of less concern than the need to let people see that a record was being made. In the Aegean case focusing on the physical aspects of writing in relation to the types of material supports rather than on the decipherment and understanding of texts can provide additional insight concerning the social role of writing in societies in which literacy would have been very limited.

\section{References}

Alexiou, S. and W. C. Brice 1972. A Silver Pin from Mavro Spelio with an Inscription in Linear A: Her. Mus. 540. Kadmos 11(2): 113-124. DOI: http://dx.doi.org/10.1515/kadm.1972.11.2.113

Alexiou, S. and W. C. Brice 1976. A Silver Pin from Platanos with an Inscription in Linear A: Her. Mus. 498. Kadmos 15(1): 18-27. DOI: http://dx.doi.org/10.1515/kadm.1976.15.1.18

Bass, G. F. 1986. A Bronze Age Shipwreck at Ulu Burun (Kaş): 1984 campaign. American Journal of Archaeology 90(3): 269-296. DOI: http://dx.doi.org/10.2307/505687

Bass, G. F., Pulak, C., Collon, D. and Weinstein, J. 1989. The Bronze Age Shipwreck at Ulu Burun: 1986 Campaign. American Journal of Archaeology 93(1): 1-29. DOI: http://dx.doi. org/10.2307/505396 
Bendall, L. 2013. The Aegean Bronze Age Scripts. In Galanakis, Y. (ed.), The Aegean World. A guide to the Cycladic, Minoan and Mycenaean antiquities in the Ashmolean Museum. Oxford: Archeopress, 133-152.

Branigan, K. 1970. The Tombs of Mesara: A Study of funerary architecture and ritual in Southern Crete, 2800-1700 B.C. London: Gerald Duckworth.

Brown, M. P. 1994. The Role of the Wax Tablet in Medieval Literacy: A recent find from York. The British Library Journal 20: 1-16.

Chadwick, J. 1976. The Mycenaean World. Cambridge: Cambridge University Press.

Clanchy, M. T. 1979. From Memory to Written Record: England 1066-1307. London: Edward Arnold.

Cornell, T. 1991. The Tyranny of the Evidence: A discussion of the possible uses of literacy in Etruria and Latium in the Archaic Age. In Literacy in the Roman World (Journal of Roman Archaeology Supplementary Series 1). Ann Arbor: Journal of Roman Archaeology, 7-33.

Cribiore, R. 1996. Writing, Teachers, and Students in Graeco-Roman Egypt. Atlanta: Scholars Press.

Crielaard, J. P. 1995. Homer, History and Archaeology: Some remarks on the date of the Homeric world. In Crielaard, J. P. (ed.), Homeric Questions: Essays in philology, ancient history and archaeology, including the papers of a conference organized by the Netherlands Institute at Athens (15 May 1993). Amsterdam: J. C. Gieben, 201-288.

Cultraro, M. 2006. I Micenei: Archeologia, stori, società dei Greci prima di Omero. Rome: Carocci editore.

Fri, M. L. 2007. The Double Axe in Minoan Crete: A functional analysis of production and use. Unpublished $\mathrm{PhD}$ dissertation, Stockholm University.

Godart, L. 1999. L'écriture d’Arkhanès: Hiéroglyphique ou Linéaire A? In Betancourt, P. P., Karageorghis, V., Laffineur, R. and Niemeier, W.-D. (eds), Meletemata: Studies in Aegean Archaeology Presented to Malcolm H. Wiener as He Enters his $65^{\text {th }}$ Year. Liège: Université de Liège, 299-302.

Godart, L. and Olivier, J.-P. 1982. Receuil des Inscriptions en Linéaire A (Études crètoises 21). Paris: École française d'Athènes.

Hallager, E. 1996. The Minoan Roundel and Other Sealed Documents in the Neopalatial Linear A Administration. Volume 1 (Aegaeum 14). Liège: Université de Liège, Histoire de l'art et archéologie de la Grèce antique.

Hood, S. 1984. A Minoan Empire in the Aegean in the $16^{\text {th }}$ and $15^{\text {th }}$ Centuries B.C. In Hägg, R. and Marinatos, N. (eds), The Minoan Thalssocracy, Myth and Reality: Proceedings of the Third International Symposium at the Swedish Institute in Athens, 31 May-5 June, 1982. Stockholm: Swedish Institute in Athens, 33-37.

Hood, S. 1987. Mason's Marks in the Palaces. In Hägg, R. and Marinatos, N. (eds), The Function of the Minoan Palaces: Proceedings of the Fourth International Symposium of the Swedish Institute in Athens, 10-16 June, 1984. Stockholm: Swedish Institute in Athens, 205-212.

Janko, R. 1982. A Stone Object Inscribed in Linear A from Ayios Stephanos, Laconia. Kadmos 21: 97-100.

Karo, G. 1930-1933. Die Schachtgräber von Mykenai. Munich: F. Bruckmann.

Karytinos, A. 1998. Sealstones in Cemeteries: A display of social status. In Branigan, K. (ed.), Cemetery and Society in the Aegean Bronze Age. Sheffield: Sheffield Academic Press, 78-86.

Keates, S. 2002. The Flashing Blade: Copper, colour and luminosity in North Italian Copper Age society. In Jones, A. and MacGregor, G. (eds), Colouring the Past: The significance of colour in archaeological research. Oxford: Berg, 109-125. 
Krzyszkowska, O. 2005. Aegean Seals: An introduction. London: Institute of Classical Studies.

Lalou, É. 1992. Inventaire des tablettes médiévales et présentation générale. In Lalou, É. (ed.), Les tablettes à écrire de l'Antiquité à l'époque modern. Turnhout: Brepols, 233-288.

MacGinnis, J. 2002. The Use of Writing Boards in the Neo-Babylonian Temple Administration at Sippar. Irak 64: 217-236. DOI: http://dx.doi.org/10.2307/4200524

Mallowan, M. E. L. 1954. The Excavations at Nimrud (Kalhu), 1953. Iraq 16(1): 59-114. DOI: http://dx.doi.org/10.2307/4199583

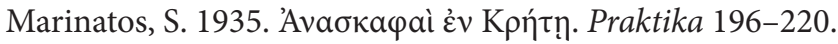

Michailidou, A. 1992-1993. 'Ostrakon' with Linear A Script from Akrotiri (Thera): A non-bureaucratic activity? Minos 27-28: 7-24.

Murphy, J. 1998. Ideologies, Rites and Rituals: A view of prepalatial Tholoi. In Branigan, K. (ed.), Cemetery and Society in the Aegean Bronze Age. Sheffield: Sheffield University Press, 27-40.

Nikolaidou, M. 1999. Formulaic Uses of Religious Imagery in Protopalatial Crete. In Betancourt, P. P., Karageorghis, V., Laffineur, R. and Niemeier, W.-D. (eds), Meletemata: Studies in Aegean Archaeology Presented to Malcolm H. Wiener as He Enters his $65^{\text {th }}$ Year. Liège: Université de Liège, 555-559.

Olivier, J.-P. 1986. Cretan Writing in the Second Millennium B. C. World Archaeology 17(3): 377389. DOI: http://dx.doi.org/10.1080/00438243.1986.9979977

Olivier, J.-P. and Godart, L. (eds) 1996. Corpus Hieroglyphicarum Inscriptionum Cretae. Paris: De Boccard.

Olivier, J.-P., Godart, L. and Laffineur, R. 1981. Un épingle minoenne en or avec inscription en Linéaire A. Bulletin de correspondance hellénique 105: 3-25.

Palaima, T. G. 2003a. The Inscribed Bronze 'Kessel' from Shaft Grave IV and Cretan Heirlooms of the Bronze Artist Names 'Aigeus' vel sim. in the Mycenaean Palatial Period. In Duhoux, Y. (ed.), Briciaka: A tribute to W. C. Brice. Amsterdam: Adolf M. Hakkert, 187-201.

Palaima, T. 2003b. 'Archives' and 'Scribes' and Information Hierarchy in Mycenaean Greek Linear B Records. In Brosius, M. (ed.), Ancient Archives and Archival Traditions: Concepts of recordkeeping in the ancient world. Oxford: Oxford University Press, 153-194.

Parisinou, E. 2005. Brightness Personified: Light and divine image in ancient Greece. In Stafford, E. and Herrin, J. (eds), Personification in the Greek World: From antiquity to Byzantium. London: Centre for Hellenic Studies, King's College London, 29-43.

Payton, R. 1991. The Ulu Burun Writing-Board Set. Anatolian Studies 41: 99-106. DOI: http:// dx.doi.org/10.2307/3642932

Perna, M. 2007. Homer and the "Folded Wooden Tablets". In Morris, S. P. and Laffineur, R. (eds), Epos: Reconsidering Greek epic and Aegean Bronze Age archaeology. Proceedings of the $11^{\text {th }}$ International Aegean Conference / 11e Rencontre égéenne internationale Los Angeles, UCLA - The J. Paul Getty Villa, 20-23 April 2006. Liège and Austin, TX: Université de Liège and University of Texas at Austin, 225-231.

Pini, I. 1990. The Hieroglyphic Deposit and the Temple Repositories at Knossos. In Palaima, T. G. (ed.), Aegean Seals, Sealings and Administration: Proceedings of the NEH-Dickson Conference of the Program in Aegean Scripts and Prehistory of the Department of Classics, University of Texas at Austin, January 11-13, 1989. Liège: Université de Liège, 33-51.

Platon, N. 1971. Zakros: The discovery of a lost palace of ancient Crete. New York: Charles Scribner's Sons.

Platon, N. and Pini, I. 1984. Die Siegel der Neupalastzeit (Corpus der minoieschen und mykenischen Siegel II.3). Berlin: G. Mann.

Postgate, N., Wang, T. and Wilkinson, T. 1995. The Evidence for Early Writing: Utilitarian or ceremonial? Antiquity 69: 459-480. 
Protonotariou-Deilaki, E. 1990. Burial Customs and Funerary Rites in the Prehistoric Argolid. In Hägg, R. and Nordquist, G. (eds), Celebrations of Death and Divinity in the Bronze Age Argolid. Stockholm: Swedish Institute in Athens, 69-83.

Rehak, P. and Younger, J. 2001. Neopalatial: Final Palatial, and Postpalatial Crete. In Cullen, T. (ed), Aegean Prehistory: A review (American Journal of Archaeology Supplement 1). Boston: Archaeological Institute of America, 383-465.

Sakellarakis, J. A. and Sapouna-Sakellaraki, E. 1997. Archanes: Minoan Crete in a new light, 2 volumes. Athens: Ammos Publications.

Sakellarakis, J. A. and Sapouna-Sakellaraki, E. 1991. Apxávec. Athens: Ekdotike Athenon.

Schoep, I. 1994. Ritual, Politics and Script on Minoan Crete. Aegean Archaeology 1: 7-25.

Schoep, I. 1999. The Origins of Writing and Administration on Crete. Oxford Journal of Archaeology 18(3): 265-276. DOI: http://dx.doi.org/10.1111/1468-0092.00083

Schoep, I. 2002. The Administration of Neopalatial Crete: A critical assessment of the Linear A tablets and their role in the administrative process (Minos Suplementos 17). Salamanca: Ediciones Universidad de Salamanca.

Schoep, I. 2004. The Socio-Economic Context of Seal Use and Administration at Knossos. In Cadogan, G., Hatzaki, E. and Vasilakis, A. (eds), Knossos: Palace, City, State. London: British School at Athens, 283-293.

Schoep, I. 2006. Looking Beyond the First Palaces: Elites and the agency of power in EM IIIMM II Crete. American Journal of Archaeology 110(1): 37-64. DOI: http://dx.doi.org/10.3764/ aja.110.1.37

Schoep, I. 2007. The Social and Political Context of Linear A Writing on Crete. In Lomas, K., Whitehouse, R. D. and Wilkins, J. B. (eds), Literacy and the State in the Ancient Mediterranean. London: Accordia Research Institute, 53-62.

Shear, I. M. 1998. Bellerophon Tablets from the Mycenaean World? A tale of seven bronze hinges. Journal of Hellenic Studies 118: 187-189. DOI: http://dx.doi.org/10.2307/632241

Shelmerdine, C. W. 2008. Background, Sources, and Methods. In Shelmerdine, C. (ed.), The Cambridge Companion to the Aegean Bronze Age. Cambridge: Cambridge University Press, 1-18. DOI: http://dx.doi.org/10.1017/CCOL9780521814447.001

Small, J. P. 1997. Wax Tablets of the Mind: Cognitive studies of memory and literacy in Classical antiquity. London and New York: Routledge. DOI: http://dx.doi.org/10.4324/9780203441602

Stoddart, S. and Whitley, J. 1988. The Social Context of Literacy in Archaic Greece and Etruria. Antiquity 62: 761-772.

Symington, D. 1991. Late Bronze Age Writing-Boards and Their Uses: Textual evidence from Anatolia and Syria. Anatolian Studies 41: 111-123. DOI: http://dx.doi.org/10.2307/3642934

Thomas, R. 1992. Literacy and Orality in Ancient Greece. Cambridge: Cambridge University Press. DOI: http://dx.doi.org/10.1017/CBO9780511620331

Warren, P. 1969. Minoan Stone Vases. Cambridge: Cambridge University Press.

Watrous, L. V. 2001. Crete from Earliest Prehistory through the Protopalatial Period. In Cullen, T. (ed.), Aegean Prehistory: A review (American Journal of Archaeology Supplement 1). Boston: Archaeological Institute of America, 157-223.

Weingarten, J. 1983. The Zakro Master and his Place in Prehistory. Göteborg: Paul Åströms förlag. Whittaker, H. 2005. Social and Symbolic Aspects of Minoan Writing. European Journal of Archaeology 8(1): 29-41. DOI: http://dx.doi.org/10.1177/1461957105058207

Younger, J. C. and Rehak, P. 2008. Minoan Culture: Religion, burial customs, and administration. In Shelmerdine, C. (ed.), The Cambridge Companion to the Aegean Bronze Age. Cambridge: Cambridge University Press, 165-185. DOI: http://dx.doi.org/10.1017/CCOL9780521814447.008 